\title{
Motility-Associated and Cyclic AMP-dependent Protein Phosphorylation in the Sperm of the Chum Salmon, Oncorhynchus keta
}

\author{
Atsuko ITOH ${ }^{1,3}$, Kazuo INABA ${ }^{2}$, Masakatsu FuJINOKI ${ }^{3}$ and Masaaki Morisawa' \\ 'Misaki Marine Biological Station, Graduate School of Science, the University of Tokyo, Koajiro, Misaki, Miura, Kanagawa, 238-0225, \\ Japan; ${ }^{2}$ Asamushi Marine Biological Station, Tohoku University, Sakamoto, Asamushi, Aomori, 039-3501, Japan; ${ }^{3}$ Department of Physiol- \\ ogy, Dokkyo University School of Medicine, Mibu, Tochigi, 321-0293, Japan
}

(Received 12 November 2001; and accepted 10 December 2001)

\begin{abstract}
Cyclic AMP-dependent cell signaling pathway has been considered to play an essential role in the initiation of sperm motility in salmonid fishs. We showed here that inhibitors of cyclic AMP-dependent protein kinase blocked the motility of the sperm of chum salmon whose plasma membrane was removed with TritonX-100. Seven proteins, which were phosphorylated by cAMP concomitantly with motility initiation of the demembranated sperm, were identified. Among them two proteins were identified as $21 \mathrm{kDa}$ light chain of the outer arm dynein and $48 \mathrm{kDa}$ regulatory subunit of protein kinase-A (PKA) from their molecular masses. Five proteins had the molecular masses of $28 \mathrm{kDa}, 33 \mathrm{kDa}, 41 \mathrm{kDa}, 63 \mathrm{kDa}$ and $83 \mathrm{kDa}$. Phosphorylation of these proteins as well as the motility of the demembranated sperm were significantly inhibited by the PKA inhibitors. When the demembranated sperm were prepared after pre-activation, all of these 7 proteins had less labeled ${ }^{32} \mathrm{P}$. These results suggest that cAMP-dependent phosphorylation of multiple proteins through activation of PKA is involved in the initiation of sperm motility in the salmonid fish.
\end{abstract}

Cyclic AMP is one of the essential second messengers for the regulation of sperm motility in starfish (11), sea urchin $(11,3)$, tunicate (3), salmonid fishes $(19,20)$ and mammals $(6,15,27,30)$. It has been reported that the increase in CAMP concentration in sperm causes activation of cAMP-dependent protein kinase (A-kinase, PKA) (29). The kinase phosphorylates several flagellar proteins, including the regulatory subunit of PKA $(6,9,25,29)$ and the light chain of the outer arm dynein $(1,9,10,28)$. Sperm of salmonid fishes whose motility is triggered by a decrease in the extracellular potassium ion concentration at spawning (18) have provided a novel

Correspondence to: Atsuko Itoh

Misaki Marine Biological Station, Graduate School of Science, the University of Tokyo, Koajiro, Misaki, Miura, Kanagawa, 238-0225, Japan

Tel: +81-468-81-4105 Fax: +81-468-81-7944

E-mail: atsuko@mmbs.s.u-tokyo.ac.jp model for understanding the molecular mechanism of the regulation of sperm motility. The decrease in $\mathrm{K}^{+}$surrounding sperm activates adenylyl cyclase, resulting in an increase in the intracellular cAMP concentration (22). The synthesized cyclic AMP phosphorylates $22 \mathrm{kDa}$ dynein light chain (10), the $48 \mathrm{kDa}$ regulatory subunit of PKA (9) and $15 \mathrm{kDa}$ protein $(5,12,21)$. The $15 \mathrm{kDa}$ protein is phosphorylated at tyrosine residues in a cAMP-dependent manner (5), possibility through activation of tyrosine kinase by PKA and is localized at the base of the flagellum, a part that is close to the centrioles of sperm (13). On the other hand, the dynein light chain and the PKA regulatory subunit have been isolated from the axoneme of sperm flagella $(9,10)$ and considered to be located along the axoneme of the sperm flagellum. These suggest that two cascade processes in regard to CAMP-dependent protein phosphorylation are involved in the initiation of sperm motility in salmonid fishes. 
Five new proteins whose phosphorylation was inhibited by PKA inhibitors and associated with sperm motility were identified. Furthermore, ${ }^{32} \mathrm{P}-1 \mathrm{a}-$ beling did not occur in the five proteins isolated from the demembranated sperm whose motility had been initiated in $\mathrm{K}^{+}$-free medium before the demembranation, suggesting that multiple cAMP-dependent protein phosphorylation, at least in the five proteins, is associated with the initiation of sperm motility in the salmonid fish.

\section{MATERIALS AND METHODS}

Chemicals. H-89 ( $N$-[2-( $p$-bromocinnamylamino) ethyl]-5-isoquinolinesulfonamide) and H-85 ( $N$-[2( $N$-formyl-p-chlorocinnamylamino) ethyl]-5-isoquinolinesulfonamide) were purchased from Seikagaku Kogyo Co. (Tokyo, Japan). PKAI (synthetic peptide inhibitor of PKA) was from Calbiochem Co. (Schwalbach, Germany). $\left[\gamma_{-}{ }^{32} \mathrm{P}\right] \mathrm{ATP}$ was from Dupont/NEN Life Science Products (Boston, MA, U.S.A.). Molecular markers of SDS-PAGE were from Bio-Rad (Hercules, CA). Cyclic AMP, ATP and Triton X-100 were from Wako Pure Chemical Co. (Osaka, Japan). All other reagents were purchased from Nacalai tesque (Tokyo, Japan).

H89 and H85 were dissolved in dimethyl sulfoxide (DMSO) at a final concentration of DMSO of less than $1 \%$. The concentrations had no effect on sperm motility (8).

Motility measurement of demembranated sperm. Mature males of the chum salmon, Oncorhynchus keta were captured from late October to early December in Otsuchi Bay and Otsuchi river, Iwate prefecture, Japan. Semen was obtained by inserting a Pasteur pipette into the sperm duct. Preparation of demembranated sperm was based on the method described previously (19). One volume of semen was suspended in 20 volumes of extraction medium containing $0.15 \mathrm{M} \mathrm{KCl}, 2 \mathrm{mM} \mathrm{MgCl}, 0.5 \mathrm{mM}$ EDTA, $2 \mathrm{mM}$ Tris- $\mathrm{HCl}(\mathrm{pH} 8.0), 0.04 \%$ Triton $\mathrm{X}-100$ and $0.5 \mathrm{mM}$ DTT and incubated on ice for $1 \mathrm{~min}$ to solubilize the plasma membrane of the sperm. One volume of the suspension containing the demembranated sperm was re-suspended in 25 volumes of reactivation medium containing $0.15 \mathrm{M} \mathrm{KCl}, 2 \mathrm{mM}$ $\mathrm{MgCl}_{2}, 1 \mathrm{mM}$ EGTA, $20 \mathrm{mM}$ Tris- $\mathrm{HCl}$ (pH8.0), $0.1 \mathrm{mM}$ cAMP, 2\% polyetylene glycol (molecular mass of 20,000) and $0.5 \mathrm{mM}$ DTT with or without inhibitors. The motility of the demembranated sperm was then reactivated by adding $0.5 \mathrm{mM}$ ATP to the reactivation medium. Sperm motility was recorded on a videotape via a CCD camera (Hama- matsu Photonics, Hamamatsu, Japan) attached to a microscope (Nikon, Tokyo, Japan) with phase contrast illumination and analyzed by counting motile and immotile sperm. The percentage of sperm motility was normalized by taking the percentage of motile sperm (the number of motile sperm/all sperm) in the absence of inhibitors as $100 \%$.

Phosphorylation assay and solubilization of flagellar protein. Phosphorylation assay was performed as described previously (21) with some modifications. Semen was centrifuged at $2,500 \times \mathrm{g}$ for $5 \mathrm{~min}$ at $4{ }^{\circ} \mathrm{C}$ to collect sperm. Sperm were suspended in 15 volumes of extraction medium used for preparing the demembranated sperm.

After incubation on ice for $1 \mathrm{~min}$, the suspension was centrifuged at $2,500 \times \mathrm{g}$ for $5 \mathrm{~min}$ at $4^{\circ} \mathrm{C}$. The precipitate containing the demembranated sperm was re-suspended in 3 volumes of phosphorylation assay solution containing $0.15 \mathrm{M} \mathrm{KCl}, 2 \mathrm{mM}$ $\mathrm{MgCl}_{2}, 1 \mathrm{mM}$ EGTA, $20 \mathrm{mM}$ Tris- $\mathrm{HCl}$ (pH8.0), and $0.5 \mathrm{mM}$ DTT. The protein concentration in the sperm was measured by Bradford's method (2) and adjusted to $3.8 \mathrm{mg} / \mathrm{mL}$ in the solution. Cyclic AMP $(0.1 \mathrm{mM})$ and $\left[\gamma-{ }^{32} \mathrm{P}\right]$ ATP $(0.5 \mathrm{mM}, 3 \mathrm{GBq} / \mathrm{mmol})$ were added. PKA inhibitors were added before the addition of ATP. After incubation at room temperature for $1 \mathrm{~min}$, phosphorylation of proteins was terminated by adding $7 \mathrm{M}$ urea and flagellar proteins were solubilized by continuous incubation for $15 \mathrm{~min}$ on ice. After centrifugation at $10,000 \times \mathrm{g}$ for $15 \mathrm{~min}$ at $4^{\circ} \mathrm{C}$, the supernatant was collected and analyzed by SDS-PAGE using 10\% polyacrylamide gel.

After sperm were demembranated, re-suspended sperm in reactivation medium were homogenized by POLYTORON AGR) (KINEMATICA, Luzern, Switzerland) for $10 \mathrm{~min}$ on ice. The homogenate was centrifuged at $2,000 \times g$ for $1 \mathrm{~min}$ at $4{ }^{\circ} \mathrm{C}$, and this supernatant used as 'flagellar fractions'. The flagellar fractions were assayed phosphorylation with $\left[\gamma_{-}{ }^{32} \mathrm{P}\right] \mathrm{ATP}$ and the phosphorylated flagella were collected by centrifugation at $8,000 \times g$ for $10 \mathrm{~min}$ at $4{ }^{\circ} \mathrm{C}$. The collected flagella were suspended in 20 volumes of the solution containing $0.6 \mathrm{M} \mathrm{NaCl}$, $2 \mathrm{mM} \quad \mathrm{MgCl}_{2}, 1 \mathrm{mM}$ EGTA, $20 \mathrm{mM}$ Tris-HCl (pH8.0) and $0.5 \mathrm{mM} \mathrm{DTT}$, and incubated for $30 \mathrm{~min}$ on ice. After incubation, the suspension was centrifuged at $5,000 \times \mathrm{g}$ for $30 \mathrm{~min}$ at $4^{\circ} \mathrm{C}$, and the supernatant were analyzed by SDS-PAGE using 15\% polyacrylamide gel.

$S D S-P A G E$ and autoradiography. Sample buffer containing SDS at a final concentration of $10 \%$ SDS, 15\% 2-merchapthoethanole, 40\% glycerol, 
$0.004 \%$ bromophenol blue, $312.5 \mathrm{mM}$ Tris- $\mathrm{HCl}$ (pH6.8) was added to the supernatants, and the samples were boiled for $2 \mathrm{~min}$ at $100^{\circ} \mathrm{C}$ and subjected to SDS-PAGE. SDS-PAGE was carried out according to the method of Laemmli (14). The separating gel used was $10 \%(\mathrm{w} / \mathrm{v})$ polyacrylamide containing $0.1 \%(\mathrm{w} / \mathrm{v})$ SDS. After electrophoresis, the gel was stained with Coomassie Brilliant Blue, dried and exposed to Kodak X-Omat film (Eastman-Kodak, NY, USA.) backed with an intensifying filter (Toshiba, Tokyo, Japan) for $48 \mathrm{~h}$ at $-80^{\circ} \mathrm{C}$. The degree of phosphorylation was quantified by measuring the intensity of bands on the film using NIH Image ver. 1.61. Background density was subtracted from the density of each peak that represented each band on the film and was used as the demonstrated quantity of phosphorylation of the band.

\section{RESULTS}

Effects of inhibitors of protein kinase-A on the motility of demembranated sperm

Motility of the demembranated sperm of the rainbow trout (19) and chum salmon (20), which were demembranated by Triton $\mathrm{X}-100$, is not reactivated only in the presence of ATP. The addition of cAMP causes the initiation of motility, suggesting that a cAMP dependent regulatory mechanism controls the motility initiation in salmonid sperm. To elucidate the role of cAMP-dependent protein kinase-A
(PKA) in the initiation of sperm motility, we examined the effects of several inhibitors of PKA on the reactivation of the demembranated sperm. An inhibitor, which is specific for PKA, H-89, very efficiently inhibited the reactivation of the demembranated sperm (Fig. 1). Nevertheless, H-85, which is a non-inhibitory structural analogue of $\mathrm{H}-89$, slightly inhibited the reactivation of the demembranated sperm, and the inhibitory effect was far less than that of H-89. PKAI, which is a synthetic peptide and very specific inhibitor of PKA, inhibited the reactivation of the demembranated sperm at a concentration of $20 \mathrm{nM}$.

\section{Solubilization of flagellar proteins by urea}

Sample buffer for SDS-PAGE has been used to dissolve flagellar proteins $(5,24)$. In the present study, the addition of sample buffer to sperm suspension made the solution viscous due to the solubilized DNA from sperm heads with SDS. However, when $7 \mathrm{M}$ urea was used, viscosity derived from DNA was not found, and the sperm flagellum was completely dissolved, and sperm heads remained intact (Fig. 2). Sperm heads were quickly removed by centrifugation, and flagellar proteins were recovered in the supernatant. This simple and efficient method was used for the subsequent phosphorylation studies.

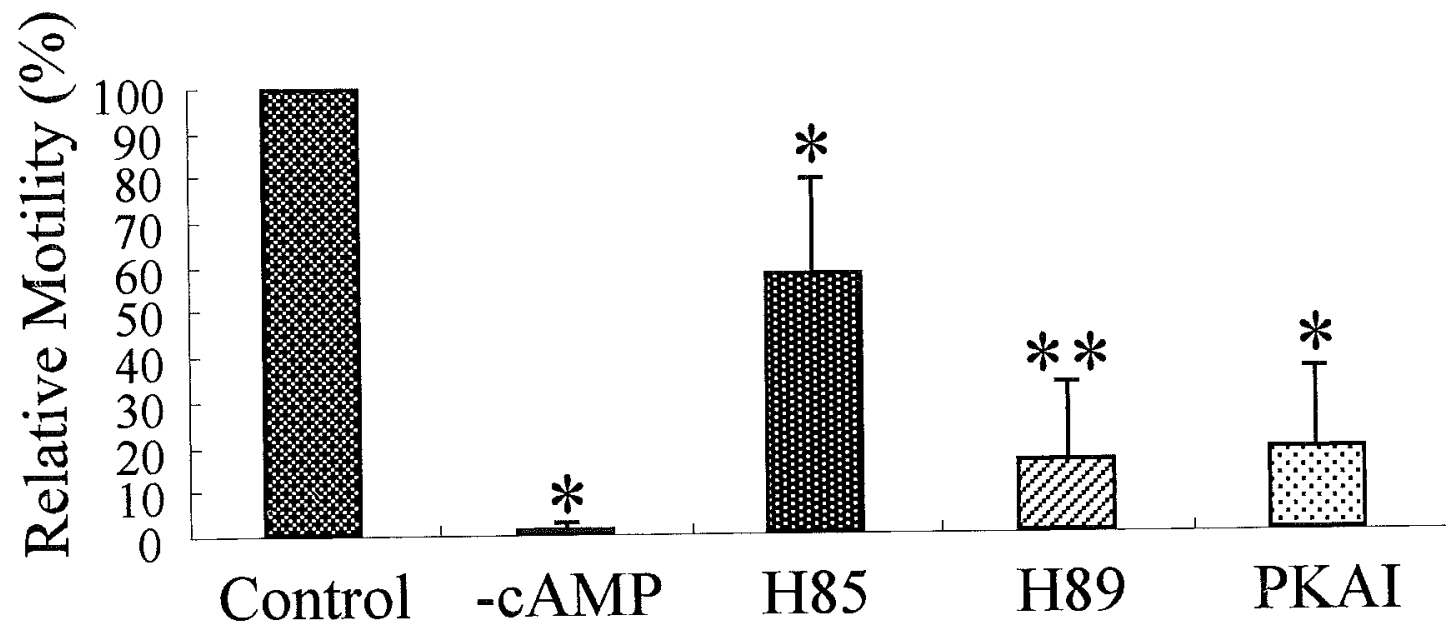

Fig. 1 Effects of PKA inhibitors on the motility of demembranated sperm. Demembranated sperm were reactivated by $0.5 \mathrm{mM}$ ATP and $0.1 \mathrm{mM}$ cAMP in the presence or absence of PKA inhibitors: H-85 $(60 \mu \mathrm{M}), \mathrm{H}-89(60 \mu \mathrm{M})$ and PKAI $(20 \mathrm{nM})$. Relative motility represents the percentage of motile sperm relative to that in the absence of inhibitors (control). Values are expressed as the mean \pm SD. Single asterisk represents significant inhibition as compared with the control $(P<0.001, \mathrm{n}=5)$. Double asterisks represent significant inhibition as compared with H-85. Note that the demembranated sperm was not reactivated in the absence of both cAMP and PKA inhibitors (-cAMP). 

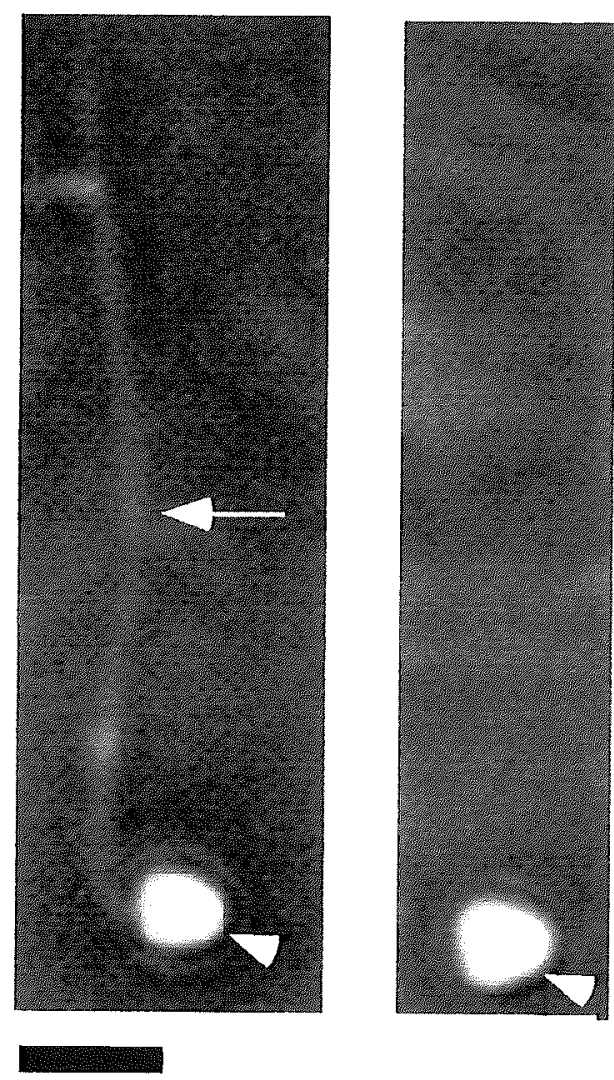

$5 \mu \mathrm{m}$

Fig. 2 Solubilization of axonemal proteins from the demembranated sperm by urea solution. Images seen through phase contrast microscope show that axoneme of the demembranated sperm (arrow) existed before incubation with $7 \mathrm{M}$ urea solution (left), and the axoneme was solubilized after urea incubation (right). Heads (arrowheads) were intact both before and after incubation. Bar represents $5 \mu \mathrm{m}$.

Detection of cAMP-dependent phosphoproteins associated with sperm motility

To elucidate the role of PKA-dependent protein phosphorylation on the initiation of sperm motility, we tried to detect phosphoproteins which are associated with reactivation of the demembranated sperm. Sperm plasma membrane was removed with Triton $\mathrm{X}-100$ and the demembranated sperm were incubated in the phosphorylation assay solution (see Materials and Methods) containing $\left[\gamma_{-}{ }^{32} \mathrm{P}\right]$ ATP. As shown in Fig. 3, (lane a), only faint ${ }^{32} \mathrm{P}_{\mathrm{i}}$ incorporations were detected in several proteins in the absence of cAMP. But phosphorylation was detected in 10 proteins with molecular masses of $21 \mathrm{kDa}$, $23 \mathrm{kDa}, 28 \mathrm{kDa}, 33 \mathrm{kDa}, 36 \mathrm{kDa}, 41 \mathrm{kDa}, 48 \mathrm{kDa}$,

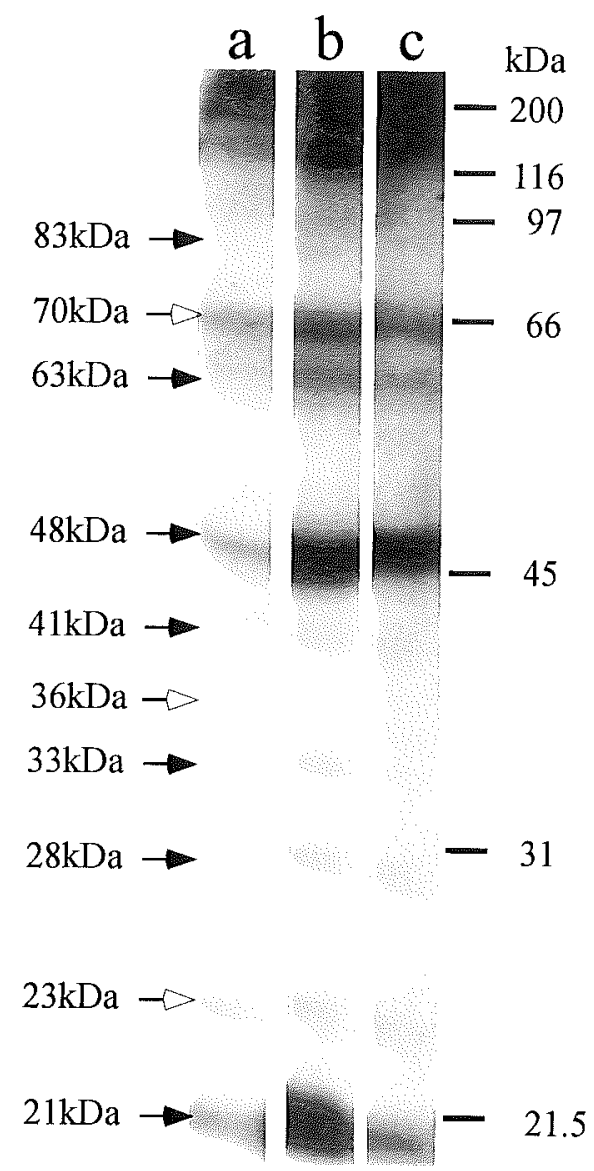

Fig. 3 Phosphorylation of flagellar proteins at the cAMP-dependent initiation of sperm motility. Demembranated sperm were immotile in the absence of cAMP (see Fig. 1), and $21 \mathrm{kDa}, 23 \mathrm{kDa}, 41 \mathrm{kDa}, 48 \mathrm{kDa}$, $63 \mathrm{kDa}$ and $70 \mathrm{kDa}$ proteins were slightly phosphorylated in the absence of cAMP (lane a). When motility of the demembranated sperm was reactivated in the presence of $0.1 \mathrm{mM}$ cAMP (lane b), 10 proteins with molecular masses of $21 \mathrm{kDa}, 23 \mathrm{kDa}, 28 \mathrm{kDa}, 33 \mathrm{kDa}$, $36 \mathrm{kDa}, 41 \mathrm{kDa}, 48 \mathrm{kDa}, 63 \mathrm{kDa}, 70 \mathrm{kDa}$ and $83 \mathrm{kDa}$ (arrows with black and white heads), were phosphorylated. In lane $c$, when intact sperm were allowed to be motile for $2 \mathrm{~min}$ and then the sperm were demembranated and reactivated by $0.1 \mathrm{mM}$ cAMP, ${ }^{32} \mathrm{P}_{i}$ incorporation were reduced in the proteins (arrows with black heads, see Table 1). The numbers on the right show molecular mass markers.

$63 \mathrm{kDa}, 70 \mathrm{kDa}$ and $83 \mathrm{kDa}$ in the presence of cAMP (Fig. 3, lane b). To examine whether the phosphorylation of these 10 proteins is really coupled with the initiation of sperm motility, we investigated phosphorylation of the demembranated sperm after in vivo activation as follows: motility of intact sperm was initiated in vivo at first by diluting one 
volume of semen to 40 volumes of $\mathrm{K}^{+}$-free medium containing $100 \mathrm{mM} \mathrm{NaCl}, 5 \mathrm{mM} \mathrm{CaCl} 2$ and $5 \mathrm{mM}$ $\mathrm{NaHCO}_{3}$. After the motility was completed the plasma membrane of the sperm was solubilized in the demembranated medium containing $\left[\gamma_{-}{ }^{32} \mathrm{P}\right] \mathrm{ATP}$ in the presence of cAMP. Incorporation of ${ }^{32} \mathrm{P}$ was significantly reduced in the seven proteins with molecular masses of $21 \mathrm{kDa}, 28 \mathrm{kDa}, 33 \mathrm{kDa}, 41 \mathrm{kDa}$, $48 \mathrm{kDa}, 63 \mathrm{kDa}$ and $83 \mathrm{kDa}$ (Fig. 3, lane c and Table 1). This reduction of ${ }^{32} \mathrm{P}$ incorporation may be due to that these proteins were already phosphorylated upon in vivo initiation of sperm motility. Three other proteins with molecular masses of $23 \mathrm{kDa}$, $36 \mathrm{kDa}$ and $70 \mathrm{kDa}$ had similar ${ }^{32} \mathrm{P}$-incorporation to that observed in lane $b$. These suggest that among phosphorylations, 7 proteins other than 23,36 and $70 \mathrm{kDa}$ are coupled with the initiation of salmonid sperm motility.

\section{Phosphoproteins extracted by high salt solution}

In order to examine the nature of cAMP dependent phosphoproteins extracted by $7 \mathrm{M}$ urea solution, we tried to extract these phosphoproteins by high salt $(0.6 \mathrm{M} \mathrm{NaCl})$ by which dynein light chain and PKA subunit could be extracted from sperm flagella (9). As a result, $21 \mathrm{kDa}$ and $48 \mathrm{kDa}$ proteins could be extracted from sperm flagella by the high salt solution (Fig. 4), suggesting that $21 \mathrm{kDa}$ and $48 \mathrm{kDa}$ protein extracted by the urea solution would be correspondent to the component of outer arm dynein and PKA. $28 \mathrm{kDa}, 33 \mathrm{kDa}$ and $41 \mathrm{kDa}$ proteins could not be extracted (Fig. 4). It is not clear whether 2 phosphoproteins in the molecular masses between $66 \mathrm{kDa}$ to $99 \mathrm{kDa}$ (Fig. 4) were $63 \mathrm{kDa}$ and $83 \mathrm{kDa}$ phosphoprotens which were showed in Fig. 3, since we used $15 \%$ polyacrylamide gel for SDS-PAGE.
Effect of PKA inhibitors on the phosphorylation of the seven phosphoproteins

H-89 and PKAI inhibited the phosphorylation of the seven proteins (Fig. 5), concomitantly with inhibition of the motility of the demembranated sperm (Fig. 1). H-85 did not significantly inhibit phosphorylation of the seven proteins (Fig. 5) or reactivation of the demembranated sperm (Fig. 1). The inhibition of phosphorylation by $\mathrm{H}-89$ was efficient in $33 \mathrm{kDa}$ and $63 \mathrm{kDa}$ proteins. Inhibition of phosphorylation by PKAI was more efficient in $28 \mathrm{kDa}$ protein than that in other proteins (Table 2). Inhibition of phosphorylation of $21 \mathrm{kDa}$ protein by $\mathrm{H}-89$ and PKAI was not prominent when compared with that of $33 \mathrm{kDa}, 63 \mathrm{kDa}$ and $28 \mathrm{kDa}$ proteins but the inhibition of $21 \mathrm{kDa}$ protein by the inhibitors was clear when compared with the control (Table 2). These results suggest that PKA-dependent phosphorylation of these seven proteins, especially that of $28 \mathrm{kDa}$, $33 \mathrm{kDa}$ and $63 \mathrm{kDa}$, plays a key role in the initiation of sperm motility in the salmonid fish.

\section{DISCUSSION}

The contribution of phosphoproteins and protein phosphorylations to sperm motility has been studied in many animal species $(1,3-6,10,21,23-25,27$ 30) but details of the roles of these phosphoproteins in cell signaling underlying the regulatory mechanism of sperm motility have been unclear. It has been suggested that cAMP-dependent phosphorylation of $15 \mathrm{kDa}$ protein $(5,21)$, dynein light chain of the outer arm (10) and regulatory subunit of protein kinase-A (9) is coupled with sperm motility in the sperm of salmonid fishes.

SDS solution, which has been widely used for solubilization of protein from cells, could not be

Table 1 Quantitative Analysis of Cyclic AMP-dependent Phosphorylation of the Ten Proteins

\begin{tabular}{c|cccccccccc}
\hline & \multicolumn{8}{|c}{ Relative densitometry $(\%)^{\mathrm{a}}$} \\
& $21 \mathrm{kDa}$ & $23 \mathrm{kDa}$ & $28 \mathrm{kDa}$ & $33 \mathrm{kDa}$ & $36 \mathrm{kDa}$ & $41 \mathrm{kDa}$ & $48 \mathrm{kDa}$ & $63 \mathrm{kDa}$ & $70 \mathrm{kDa}$ & $83 \mathrm{kDa}$ \\
\hline- cAMP & $30.3^{\mathrm{b}}$ & 27.6 & 25.8 & 14.6 & 48.6 & 24.2 & 23.6 & 19.8 & 44.3 & 21.2 \\
+ cAMP & 100.0 & 100.0 & 100.0 & 100.0 & 100.0 & 100.0 & 100.0 & 100.0 & 100.0 & 100.0 \\
pre-activat. $^{\mathrm{c}}$ & 57.8 & 99.6 & 58.2 & 52.8 & 99.0 & 36.4 & 50.2 & 49.4 & 97.9 & 55.8 \\
\hline
\end{tabular}

and intensity of the ten proteins in Fig. 3, value relative to that in the presence of cAMP.

${ }^{\mathrm{b}}$ The mean for at least four different experiments.

${ }^{\mathrm{c}}$ When intact sperm were allowed to be motile for $2 \mathrm{~min}$ and then the sperm were demembranated and reactivated in the presence of $\mathrm{cAMP}$ and $\left[\gamma{ }^{32} \mathrm{P}\right]$ ATP. 


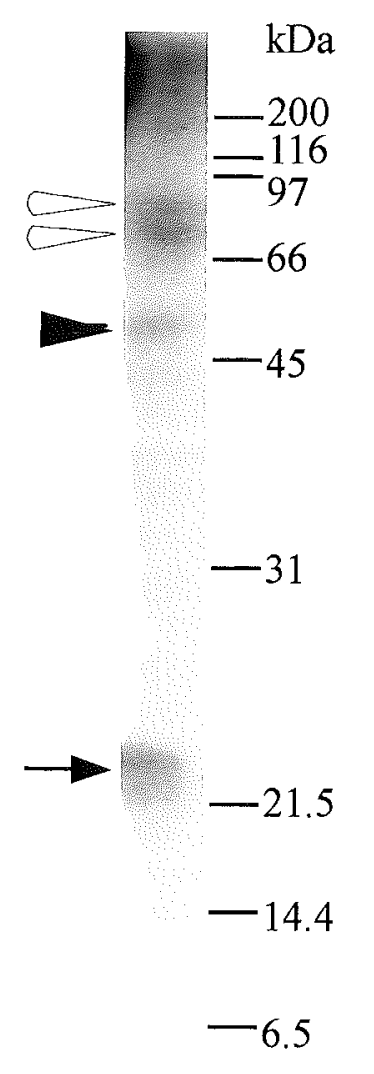

Fig. 4 Cyclic AMP-dependent phosphorylation of $0.6 \mathrm{M} \mathrm{NaCl}$ extracted proteins. The high salt $0.6 \mathrm{M}$ $\mathrm{NaCl}$ could solubilize phosphorylated $21 \mathrm{kDa}$ protein (arrow) and $48 \mathrm{kDa}$ protein (arrowhead) from sperm flagella. Molecular masses of phosphoproteins indicated with white arrowheads could not be identified in $15 \%$ polyacrylamide gel. The numbers on the right show molecular mass markers.

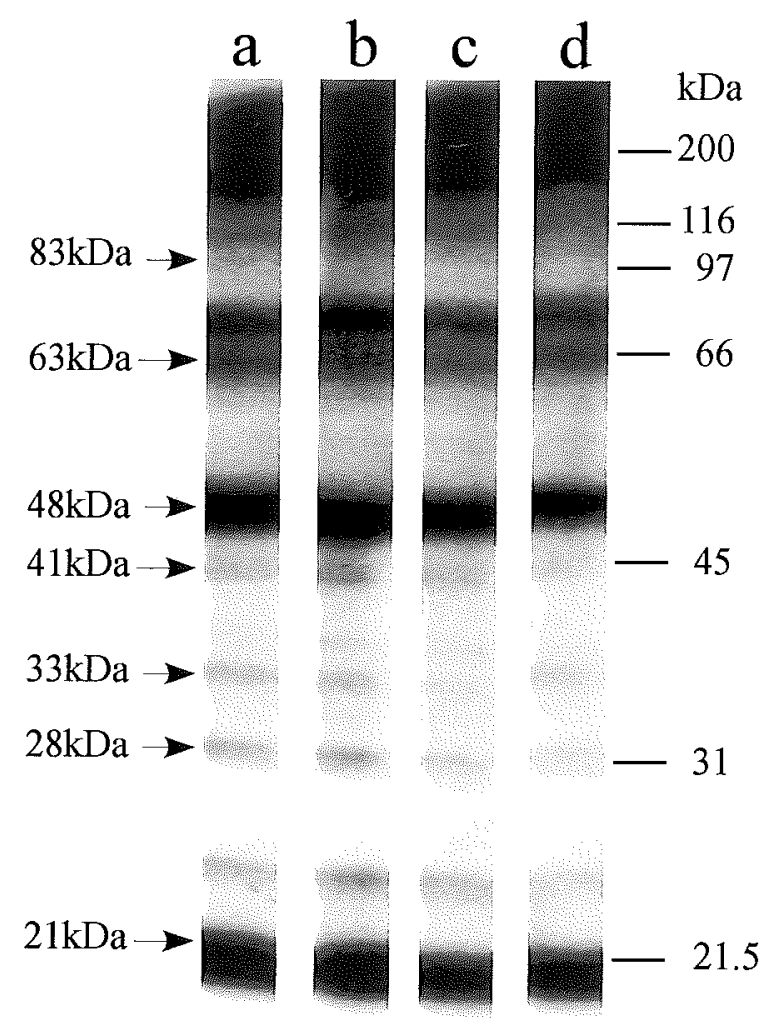

Fig. 5 Effects of PKA inhibitors on the phosphorylation of proteins. Demembranated sperm were reactivated with $0.1 \mathrm{mM}$ cAMP and $\left[\gamma_{-}{ }^{32} \mathrm{P}\right] \mathrm{ATP}$ in the absence (lane a) and presence of PKA inhibitors; $60 \mu \mathrm{M} \mathrm{H}-85$ (lane b), $60 \mu \mathrm{M} \mathrm{H}-89$ (lane c) and $20 \mathrm{nM}$ PKAI (lane d). Proteins were separated by SDS-PAGE and subjected to autoradiography. Phosphorylation of seven proteins that were identified as proteins phosphorylated in association with sperm motility (see Fig. 3) was inhibited by PKAI. The numbers on the right show molecular mass markers

Table 2 Quantitative Analysis of the Effect of PKA Inhibitors on Phosphorylation of the Seven Proteins

\begin{tabular}{cc|ccccccc}
\hline & & \multicolumn{7}{|c}{ Relative densitometry $(\%)^{\mathrm{a}}$} \\
Inhibitor & Concentation & $21 \mathrm{kDa}$ & $28 \mathrm{kDa}$ & $33 \mathrm{kDa}$ & $41 \mathrm{kDa}$ & $48 \mathrm{kDa}$ & $63 \mathrm{kDa}$ & $83 \mathrm{kDa}$ \\
\hline- & - & $100.0^{\mathrm{b}}$ & 100.0 & 100.0 & 100.0 & 100.0 & 100.0 & 100.0 \\
H-85 & $60 \mu \mathrm{M}$ & 67.8 & 53.0 & 55.1 & 73.9 & 70.2 & 68.3 & 63.7 \\
H-89 & $60 \mu \mathrm{M}$ & 43.7 & 27.2 & 22.7 & 46.4 & 47.2 & 30.4 & 36.7 \\
PKAI & $20 \mathrm{nM}$ & 52.5 & 36.2 & 44.6 & 48.2 & 53.1 & 52.0 & 45.8 \\
\hline
\end{tabular}

${ }^{\mathrm{a}}$ Band intensity of the seven proteins in Fig. 4, value relative to that in the absence of inhibitors.

${ }^{\mathrm{b}}$ The mean for at least three different experiments. 
used in salmonid sperm, since the addition of SDS to sperm suspension results in high viscosity of the solution which makes it difficult to analyze flagellar proteins by SDS-PAGE. In the present study, urea was able to certainly and quickly solubilize flagellar proteins without distuption of the sperm head (see Fig. 2). In addition, the $15 \mathrm{kDa}$ protein $(5,21)$ whose phosphorylation could not be detected in the axoneme isolated by the conventional homogenization method (10), and therefore considered to be localized at the base of the flagellum (13), could be detected by the urea method (data not shown). This suggests that the procedure could solubilize the entire flagellum including its basal part. By this method we have detected seven proteins phosphorylated in association with the cAMP-dependent reactivation of the demembranated sperm (Fig. 3, Table 1). Among them, $21 \mathrm{kDa}$ and $48 \mathrm{kDa}$ proteins were considered to be the light chain of the outer arm dynein and the regulatory subunit of proteins kinaseA (9), respectively, judging from the molecular masses and prominent phosphorylation pattern (see Fig. 3). Five other phosphoproteins $(28 \mathrm{kDa}$, $33 \mathrm{kDa}, 41 \mathrm{kDa}, 63 \mathrm{kDa}$ and $83 \mathrm{kDa}$ ) was first found and described in detail in the present study. The phosphorylation of the five proteins as well as $21 \mathrm{kDa}$ and $48 \mathrm{kDa}$ proteins and the reactivation of demembranated sperm were inhibited by the inhibitors of PKA (see Fig. 1, 5 and Table 2). These results suggest that all of the cAMP-dependent phosphorylation of the sperm proteins is involved in the cell signaling underlying the initiation of sperm motility in the salmonid fish.

Several studies suggest that PKA is localized near the outer arm dynein and is involved in the phosphorylation of $21 \mathrm{kDa}$ dynein light chain-related Tctex 2 (t-complex testis expressed 2)-related $(9,10)$. Tctex 2 is coded in the t-complex gene which participates in transmission ratio distortion and male infertility in mice (16). It is therefore possible that the $21 \mathrm{kDa}$ light chain of the outer arm dynein and the $48 \mathrm{kDa}$ regulatory subunit of PKA, which are phosphorylated in association with CAMP-dependent initiation of sperm motility, are closely distributed with each other in the sperm flagellum in the salmonid fish. On the other hand, PKA is present in several subfractions of flagellar axoneme, even in subfractions from the outer-arm-depleted axoneme in sea urchin sperm (1), suggesting that PKA-dependent phosphorylation occurs in an axonemal structure other than outer arm dynein. Several subunits which are composed of radial spoke, a structural component of axoneme, are known as phosphoproteins (26). PKA- dependent phosphorylation was reported in the intermediate chain of inner arm dynein from the flagellum of Chlamydomonas $(17,26)$. In ascidian Ciona, a protein from axoneme with a molecular mass of $26 \mathrm{kDa}$, is phosphorylated in association with the activation of sperm motility (4). The $26 \mathrm{kDa}$ protein is not extracted by a high salt solution and considered to be a component of the structure of axoneme other than outer arm dynein (24), which can be easily solubilized from sperm axoneme by high salt solution (7). The dynein light chain (Fig. 4. See also ref. 9) and regulatory subunit of PKA (Fig.4) could be solubilized by the high salt solution from the axoneme of sperm of the chum salmon but at least 3 of the five phosphoproteins detected in this study could not be solubilized by the high salt solution, and only urea solution could solubilize them. From the evidence accumulated in past and present studies, it is possible that high salt soluble $21 \mathrm{kDa}$ and $48 \mathrm{kDa}$ proteins and urea soluble five phosphoproteins, which might be unknown components of an axonemal structure, form the multiple phosphoprotein networks. Further study on the localization of these proteins in the axoneme may lead us to a clearer understanding of the PKA-dependent pathway for the initiation of sperm motility.

\section{Acknowledgements}

The authors thank the director and staff of Otsuchi Marine Research Center, Ocean research Institute, the University of Tokyo and the staff of Otsuchi Fisherman Union Association for supplying materials. This work was supported in part by Grant's inAid from Ministry of Education, Science, Sports and Culture to M. M. and K. I.

\section{REFERENCES}

1. Bracho, G. E., Fritch, J. and Tash, J. S. (1998) Identification of flagellar proteins that initiate the activation of sperm motility in vivo. Biochem. Biophys. Res. Commun. 242, 231-237

2. Bradford, M. M. (1976) A rapid and sensitive method for the quantitation of microgram quantities of protein utilizing the principle of protein dye binding. Anal. Biochem. 72, 248-254

3. Brokaw, C. J. (1984) Cyclic AMP-dependent activation of sea urchin and tunicate sperm motility. Ann. N. Y. Acad. Sci. 438, 132-141

4. Dey, C. S. and Brokaw, C. J. (1991) Activation of Ciona sperm motility: phosphorylaiton of dynein polypeptides and effects of a tyrosine kinase inhibitor. J. Cell Sci. 100, 815-824

5. Hayashi, H., Yamamoto, K., Yonekawa, H. and Morisawa, M. (1987) Involvement of tyrosine protein kinase in the initiation of flagellar movement in rainbow trout spermatozoa. $J$. Biol. Chem. 262, 16692-16698

6. Horowitz, J. A., Wasco, W., Leiser, M. and Orr, G. A. (1988) 
Interaction of the regulatory subunit of a type II cAMP-dependent protein kinase with mammalian sperm flagellum. $J$. Biol. Chem. 263, 2098-2104

7. Inaba, K. and Mohri, H. (1989) Dynamic conformational changes of $21 \mathrm{~S}$ dynein ATPase coupled with ATP hydrolysis revealed by proteolytic digestion. J. Biol. Chem. 246, 83848388

8. Inaba, K. and Morisawa, M. (1991) A chymotrypsin-like protease involves in motility of sperm in salmonid fish. Bionedical Res. 12, 435-437

9. Inaba, K., Morisawa, S. and Morisawa, M. (1998) Proteasomes regulate the motility of salmonid fish sperm through modulation of cAMP-dependent phosphorylation of an outer arm dynein light chain. J. Cell Sci. 111, 1105-1115

10. Inaba, K., Kagami, O. and Ogawa, K. (1999) Tctex-2-related outer arm dynein light chain is phosphorylated at activation of sperm motility. Biochem. Biophys. Res. Commun. 256, 177 $-183$

11. Ishiguro, K., Murofushi, H. and Sakai, H. (1982) Evidence that cAMP-dependent protein kinase and a protein factor are involved in reactivation of Triton X-100 models of sea urchin and starfish spermatozoa. J. Cell Biol. 92, 777-782

12. Jin, Z, X., Nakajima, T., Morisawa, M. and Hayashi, H. (1994) Isolation and properties of a protein complex containing flagellar movement-initiating phosphoprotein from testes of white salmon. $J$. Biochem. 115, 552-556

13. Jin, Z. X., Inaba, K., Manaka, K., Morisawa, M. and Hayashi, H. (1994) Monoclonal antibodies against the protein complex that contains the flagellar movement-initiating phosphoprotein of Oncorhynchus keta. J. Biochem. 115, 885-890

14. Laemmli, U. K. (1970) Cleavage of structural proteins during the assembly of the head of bacteriophage T4. Nature 227, 680-685

15. Lindemann, C. B. (1978) A cAMP-induced increase in the motility of demembranated bull sperm models. Cell 13, 9-18

16. Lyon, M. F. (1986) Male sterility of the mouse $t$-complex is due to homozygosity of the distorter genes. Cell $44,357-363$

17. Mitchell, D. R. (2000) Chlamydomonas flagella. J. Phycol. 36, 261-273

18. Morisawa, M. and Suzuki, K. (1980) Osmolality and potassium ion: Their roles in initiation of sperm motility in teleosts. Science 210, 1145-1147

19. Morisawa, M. and Okuno, M. (1982) Cyclic AMP induces maturation of trout sperm axoneme to initiate motility. $\mathrm{Na}$ ture 295, 703-704

20. Morisawa, M., Okuno, M., Suzuki, K., Morisawa, S. and Ishida, K. (1983) Initiation of sperm motility in teleosts. $J$. Submicroscopic Cytol. 15, 61-65

21. Morisawa, M. and Hayashi, H. (1985) Phosphorylation of a $15 \mathrm{~K}$ axonemal protein is the trigger initiating trout sperm motility. Biomedical Res. 6, 181-184

22. Morisawa, M. and Ishida, K. (1987) Short-term changes in levels of cyolic AMP, adenylate cyclase, and phosphodiesterase during the initiation of sperm motility in rainbow trout. J. Exp. Zool. 242, 199-204

23. Morisawa, M. (1994) Cell signaling mechanisms for sperm motility. Zool. Sci. 11, 647-662

24. Nomura, M., Inaba, K. and Morisawa, M. (2000) Cyclic AMP- and calmodulin-dependent phosphorylation of 21 and $26 \mathrm{kDa}$ proteins in axonemes is a prerequisite for SAAF-induced motile activation in ascidian spermatozoa. Dev. Growth Differ. 42, 129-138

25. Paupard, M. C., MacLeod, J., Wasco, W. and Orr, G. A. (1988) Major 56,000-dalton, soluble phosphoprotein present in bovine sperm is the regulatory subunit of a type II cAMPdependent protein kinase. J. Cell. Biochem. 37, 161-175

26. Porter M. E. and Sale, W. S. (2000) The $9+2$ axoneme anchors multiple inner arm dyneins and a network of kinases and phosphatases that control motility. J. Cell Biol. 151, F37F42

27. Si, Y. and Okuno, M. (1995) Activation of mammalian sperm motility by regulation of microtubule sliding via cyclic adenosine 5'-monophosphate-dependent phosphorylation. Biol. Reprod. 53, 1081-1087

28. Stephens, R. E. and Prior, G. (1992) Dynein from serotonin-activated cilia and flagella: extraction characteristics and distinct sites for cAMP-dependent protein phosphorylation. $J$. Cell Sci. 103, 999-1012

29. Tash, J. S., Kakar, S. S. and Means, A. R. (1984) Flagellar motility requires the cAMP-dependent phosphorylation of a heat-stable NP-40-soluble $56 \mathrm{kd}$ protein, Axokinin. Cell 38, $551-559$

30. Tash, J. S. (1989) Protein phosphorylation: The second messenger signal transducer of flagellar motility. Cell Motil. Cytoskel. 14, 332-339 